\title{
UVODNIK
}

\section{KONEC VARČEVANJA? Javno financiranje izobraževanja odraslih}

V začetku februarja je vlada sprejela Letni program izobraževanja odraslih v Republiki Sloveniji za leto 2017 (LPIO), ki je instrument, prek katerega vlada uresničuje Resolucijo o nacionalnem programu izobraževanja odraslih v Republiki Sloveniji za obdobje 20132020 (ReNPIO 13-20, 2014). S tem so potrjeni izobraževalni programi, ki se financirajo iz javnih sredstev, obseg in vrsta dejavnosti, potrebnih za njegovo uresničevanje, obseg sredstev, ki se zagotovijo v državnem proračunu, in ministrstva, pristojna za izvedbo programa. Na prvi pogled bi morda lahko sklepali, da država postopoma odpravlja varčevanje na področju izobraževanja odraslih in da se izobraževanju odraslih pri nas obetajo svetlejši časi. Optimizem bi lahko temeljil na dejstvu, da se je skupni znesek sredstev (71.791,340,70 evra) povečal za skoraj 13 odstotkov v primerjavi s preteklim letom in za 50 odstotkov, če znesek primerjamo s sredstvi v letu 2013, v času strogega varčevanja.

Podrobnejši pregled preteklih letnih programov izobraževanja odraslih kaže, da sta bili v letu 2013 in leta pred tem v LPIO vključeni samo dve ministrstvi, in sicer ministrstvo za izobraževanje, znanost in šport ter ministrstvo za delo, družino, socialne zadeve in enake možnosti. Kot je opredeljeno v ReNPIO 13-20, sta to nosilni ministrstvi za usmerjanje politike izobraževanja odraslih, oblikovanje instrumentov in zagotovitev javnih sredstev za izobraževanje odraslih (ReNPIO 13-20). V LPIO 2014 so se tema dvema ministrstvoma pridružila še štiri (ministrstvo za zdravje, ministrstvo za kulturo, ministrstvo za kmetijstvo in okolje in ministrstvo za notranje zadeve), v letošnjem letu pa je v LPIO vključenih že devet ministrstev; »nova « (nenosilna) ministrstva prispevajo 36 odstotkov vseh javnih sredstev. Če seštejemo letošnja sredstva nosilnih ministrstev (MIZŠ in MDDSZEM), dobimo znesek 45.761.733,00 evra, kar je manj, kot sta ministrstvi namenjali področju izobraževanja odraslih na primer v letu 2009 (58.902.439,00 evra), tik pred začetkom varčevanja.

Medresorska koordinacija je bila uvedena v skladu s priporočili Sveta Evropske unije (Svet EU, 2011), ki se nanašajo na skrb za usklajenost izobraževanja odraslih z drugimi področji politike. Kot ugotavljata Mikulec in Jelenc Krašovec (2016, str. 163), analize programov, ki jih financirajo druga, »nova « ministrstva (za zdravje, kulturo, kmetijstvo in okolje ...), kažejo, da ni vedno jasno, ali so njihova sredstva dejansko namenjena dejavnostim izobraževanja odraslih, ki jih opredeljuje ReNPIO 13-20; na splošno njihovi programi ne pripomorejo k zmanjševanju nepravičnosti, ne prispevajo k družbeni opolnomočenosti in 
dejavnemu državljanstvu ter se ne ukvarjajo s socialnimi neenakostmi na področju izobraževanja odraslih. Sredstva drugih ministrstev so namenjena njihovim lastnim dejavnostim (na primer preventiva v zdravstvu - tudi za predšolske otroke, izobraževanju določenih skupin ljudi, kot so čebelarji, vinogradniki, in podobno), ki so jih financirala tudi, preden so bila vključena v LPIO. Tako se medresorski pristop kaže kot zamegljevanje dejanske vsote sredstev za razvoj področja izobraževanja odraslih in njegovo podporo, še zlasti pa se z njim prikrije upad proračunskih sredstev za izobraževanje odraslih na dveh nosilnih ministrstvih. Da bi medresorsko sodelovanje postalo učinkovito in zagotavljalo racionalnejšo izkoriščenost sredstev, bi bilo treba vsebinsko usklajevati programe različnih ministrstev, oblikovati skupne medresorske programe ter določiti standarde kakovosti za programe, ki so uvrščeni v LPIO.

Glede na besedilo ReNPIO 13-20 je uresničevanje postavljenih ciljev v pristojnosti resornih ministrstev, odgovornih za področje izobraževanja odraslih. Za ta namen so dodeljena nacionalna sredstva, ki jih dopolnjujejo sredstva Evropskega socialnega sklada (ESS). Če pogledamo razmerje teh dveh vrst sredstev v letošnjem programu izobraževanja odraslih, lahko ugotovimo, da je ravno nasprotno; sredstva ESS (56 odstotkov) so dopolnjena z nacionalnimi sredstvi (44 odstotkov). Razmerje na nosilnih ministrstvih MIZŠ in MDDSZEM je še bolj neuravnoteženo; 24 odstotkov sredstev namenjata iz integralnega proračuna in kar 76 odstotkov iz sredstev Evropskega socialnega sklada.

Črpanje sredstev ESS je zaradi zapletenih postopkov pogosto vodilo v nestabilno financiranje in ogrožalo izvajanje programov splošnega izobraževanja odraslih, zlasti tistih, namenjenih ranljivim skupinam prebivalstva. Po ReNPIO 13-20 lahko načrtna vlaganja na področje splošnega neformalnega izobraževanja, posredno in z ustrezno razvitimi podpornimi dejavnostmi, največ pripomorejo k preseganju družbenih, medgeneracijskih in prostorskih razlik, socialni vključenosti, aktivnemu državljanstvu, kulturni razgledanosti in strpnosti do drugačnosti, na daljši rok pa tudi k dvigovanju izobrazbene ravni prebivalstva. Ker so programi splošnega izobraževanja tržno nezanimivi, jih v največjem obsegu izvajajo ljudske univerze (edine javne organizacije, katerih osnovna dejavnost je izobraževanje odraslih), pri tem pa je njihovo trajno delovanje odvisno od uspešnosti črpanja sredstev ESS.

Razpoložljiva javna sredstva ne zadostujejo za uresničevanje ciljev vseh treh prioritetnih področij, ki jih določa ReNPIO 2013-2020, to je splošno izobraževanje odraslih, izobraževanje za dvig izobrazbene ravni odraslih ter usposabljanje in izobraževanje za potrebe dela. Razmerja med prednostnimi področji ne sledijo ciljem ReNPIO 13-20; letos je splošnemu izobraževanju odraslih namenjenih 23,8 odstotka, izobraževanju za dvig izobrazbene ravni 7,3 odstotka ter izobraževanju in usposabljanju za potrebe dela 57,9 odstotka vseh sredstev. V primerjavi s prejšnjim letom so se deleži zmanjšali za splošno izobraževanje in izobraževanje za dvig izobrazbene ravni, povečali pa, podobno kot pretekla leta, za izobraževanje in usposabljanje za potrebe dela. Poleg tega je manj tudi sredstev za podporo dejavnosti izobraževanja odraslih, zlasti že nekaj let primanjkuje sredstev za razvoj novih programov in pristopov, manjkajo sredstva za razvoj kadrov in drugo. 
Še leta 2011 je delež javnih sredstev za področje formalnega izobraževanja odraslih (za dvig izobrazbene ravni) znašal 25 odstotkov vseh sredstev za izobraževanje odraslih. V naslednjih letih se je ta delež krčil (najbolj leta 2015, ko so bili temu prednostnemu področju namenjeni le še trije odstotki vseh dodeljenih proračunskih sredstev), letos znaša 7,3 odstotka vseh sredstev, namenjenih za izobraževanje odraslih, čeprav naj bi v skladu s cilji ReNPIO 13-20 znašal 20 odstotkov. Večina javnih sredstev je namenjenih kratkotrajnim oblikam usposabljanja za potrebe trga dela, to je pridobivanju hitro zastarelih in zamenljivih spretnosti in kompetenc. Krčenje javnih sredstev za dvig izobrazbene ravni in poglobljeno pridobivanje znanja odraslih je skrb zbujajoče, saj številne raziskave opozarjajo na pomembnost daljših, formalnih oblik izobraževanja, ki dejansko razširijo socialne in ekonomske možnosti posameznika ter dolgoročno zmanjšajo njegovo odvisnost od mezdnega dela in tržnih sil, s čimer se lahko izboljša tudi posameznikova dolgoročna socialna varnost.

Največji delež javnih sredstev je torej razporejenih na tretje prednostno področje, to je izobraževanje in usposabljanje za potrebe dela, ta delež tudi iz leta v leto narašča. Velik del teh sredstev je namenjenih izobraževanju in usposabljanju brezposelnih oseb, toda njihovi izhodi v zaposlitev niso znani. Ker je bila po zadnjih podatkih Statističnega urada RS (decembra 2016) stopnja registrirane brezposelnosti še vedno 10,8 odstotka (SURS, 2016), se seveda postavlja vprašanje o učinkovitosti velikega vložka sredstev v tretje prednostno področje z vidika zagotavljanja večje zaposljivosti brezposelnih oseb. V tej zvezi je stroka večkrat opozorila nosilni ministrstvi, da bi bilo nujno izvesti ovrednotenje programov tretjega prednostnega področja in na tej podlagi poiskati izboljšane rešitve na področju izobraževanja in usposabljanja za potrebe trga dela.

Podatek o deležu, ki ga država namenja izobraževanju odraslih v okviru vseh javnih izdatkov za področje izobraževanja, ni dostopen; Statistični urad Republike Slovenije prikazuje le javna sredstva za formalno izobraževanje. Po zadnjih podatkih je država leta 2015 za formalno izobraževanje namenila 1,907 milijarde evrov (SURS, 2017), istega leta pa je področje izobraževanja odraslih dobilo 45.143.276,12 evra, kar je okoli dva odstotka vseh sredstev, namenjenih formalnemu izobraževanju. Skratka, v tej primerjavi so sredstva za izobraževanje odraslih izredno skromna in ne zadoščajo za uspešno doseganje ciljev, ki so zapisani v ReNPIO 13-20. Posledice pomanjkanja javnih sredstev za izobraževanje odraslih v preteklih letih se že kažejo v praksi. Po podatkih Eurydice vključenost odraslih (25-64 let) v vseživljenjsko učenje v Sloveniji upada (Eurostat, 2016); v petih letih se je delež udeležbe zmanjšal za 4,3 odstotka (2010:16,2 odstotka; 2015: 11,9 odstotka). V izobraževanje se vključujejo predvsem tisti, ki imajo višjo izobrazbeno raven. V Sloveniji je razhajanje v vključenosti med najbolj in najmanj izobraženimi večje, kot je evropsko povprečje. Podobne so ugotovitve raziskave OECD o spretnostih odraslih (OECD, 2016), ki poudarjajo, da odrasli v Sloveniji v povprečju dosegajo nižje rezultate od povprečja $\mathrm{v}$ OECD na področju besedilnih in matematičnih spretnosti ter reševanja problemov $\mathrm{v}$ tehnološko bogatih okoljih.

Prioritetna področja in oblike izobraževanja odraslih, ki so v velikem deležu financirani iz sredstev ESS, pomembno zaznamujejo značilnosti politike izobraževanja odraslih v 
Sloveniji, in kot kaže trend krčenja nacionalnih sredstev ter naraščanje sredstev ESS, ni kmalu pričakovati sprememb. Na podlagi poglobljene analize financiranja izobraževanja odraslih v času varčevalnih ukrepov sta Mikulec in Jelenc Krašovec (2016, str. 166) v prispevku o vplivu evropeizacije na politiko izobraževanja odraslih ugotovila, da Slovenija opušča tradicijo inovativnega in socialno usmerjenega sistema izobraževanja odraslih, ki je bil razvit pred letom 2000. Vse bolj se zdi, da izobraževanje odraslih prek procesov evropeizacije in nekritičnega sprejemanja vsiljenih evropskih standardov postopoma opušča cilje, kot so socialna pravičnost, osebni in družbeni razvoj ter opolnomočenje odraslih s pomočjo izobraževanja in učenja, ter vse bolj postaja orodje tržno usmerjene družbe.

\section{Sonja Kump}

\section{LITERATURA}

Eurostat (2016). Key figures on Europe, Eurostat, Statistical books. Luxembourg: Publications Office of the European Union.

Letni programi izobraževanja odraslih v Republiki Sloveniji. Pridobljeno s http://www.mizs.gov.si/ si/delovna_podrocja/direktorat_za_srednje_in_visje_solstvo_ter_izobrazevanje_odraslih/ izobrazevanje_odraslih/arhiv_2009...2017.

Mikulec, B. in Jelenc Krašovec, S. (2016). Marketising Slovene adult education policies and practices using mechanisms of the Europeanisation of education. European journal for research on the education and learning of adults, 7(2), 151-170.

OECD (2016). Skills Matter: Further Results from the Survey of Adult Skills. OECD Skills Studies. Paris: OECD Publishing.

ReNPIO 13-20 (2014). Resolucija o nacionalnem programu izobraževanja odraslih v Republiki Sloveniji za obdobje 2013-2020. Ljubljana: Andragoški center Slovenije.

Svet EU (2011). Council Resolution on a renewed European agenda for adult learning. Pridobljeno s http://eur-lex.europa.eu/LexUriServ/LexUriServ.do?ur=OJ:C:i2011: 372:0001:0006:en:PDF.

SURS (2016). Javni izdatki za formalno izobraževanje tudi v 2015 (4,9\% BDP) nižji kot leto prej. Pridobljeno s http://www.stat.si/StatWeb/News/Index/6506.

SURS (2017). Število delovno aktivnih oseb se je v decembru 2016 glede na november 2016 zmanjšalo za $0,8 \%$. Pridobljeno s http://www.stat.si/StatWeb/News/Index/6505. 